\title{
気温上昇に伴う降水特性及び 流況変化の評価 \\ EVALUATION OF FUTURE CHANGES OF PRECIPITATION, EVAPOTRANSPIRATION AND RUNOFF DISCHARGE DUE TO GLOBAL WARMING
}

\author{
端野道夫 $1 \cdot$ 吉田弥生 $^{2} \cdot$ 吉田弘 $^{3}$ \\ Michio HASHINO, Yayoi YOSHIDA and Hiromu YOSHIDA \\ 1フェロー 工博 徳島大学教授 工学部建設工学科（テ770 徳島市南常三島町 2 丁目 1 番地） \\ 2 学生員 徳岛大学大学院工学研究科 建設工学専攻 ( 7770 徳岛市南常三島町 2 丁目 1 番地)

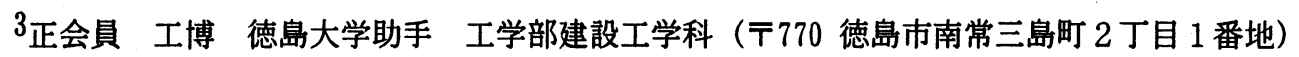

\begin{abstract}
The global warming phenomenon has become of major interest in recent years. The objective of this study is to evaluate the effects of the global warming on precipitation, evapotranspiration, and runoff discharge in two different regions with and without much snow and snowmelt in winter and spring. Two types of future temperature scenarios: Time series scenario and $1{ }^{\circ} \mathrm{C}$ increase scenario, are employed for predicting the future changes of monthly mean temperature. The occurrance number, duration, and daily rainfall amount of one storm cluster in each month for two warming scenarios are evaluated by the nonstaionary time-series model of rainfall characteristics (Nagura and Hashino, 1996). Future monthly evapotranspiration is estimated as the sum of transpitration and rainfall interception loss. Monthly mean runoff discharge is estimated by the stochastic response model of daily runoff (Yue and Hashino, 1996)
\end{abstract}

Key Words : global warming, temperature, rainfall characteristics, snow, snowmelt, filterd point process

\section{1. はじめに}

温室効果気体の増加に伴う地球規模の気候の変化 については, 地球規模の気候モデルを用いた多くの 研究が盛んにされているものの, わが国の地域的気 候に影響のある，アジアモンスーンの開始時期や梅 雨, 台風の動向については結論が得られていない 1)。また解像度や精度は不十分で信頼性は低いと 言わざるを得ない．このような状況にあっては, 過 去の蓄積された観測データに基づく統計学的モデル も，それなりの価値と有効性が高いと考えている.

本研究では, 夏期の渇水時や融雪期の日単位の流 況に与える気温上昇の影響を定量評価するには, 一 雨単位の降水特性（回数, 降雨日数, 降水量）之月 平均気温との関係の統計的定式化 ${ }^{2)}$ が重要である という認識の下に, 降水特性から日流量の積率を推 定する方法 ${ }^{3)}$ を介して, 月平均気温が流況に及ぼ す影響を評価する方法を提案する. 冬期季節風の吹 き出しや梅雨前線, 台風などの現象の時間スケール は月単位以下であるから ${ }^{4)}$, 対象とする地域の気
候はその地域の月平均気温によって，ほぼ規定され ると考える立場から解析を行う。したがって地域の 一雨単位の平均的降水特性はその地域の月平均気温 と何らかの関係があることが予想される.こうした 一雨単位の降水特性と月平均気温の関係を時系列的 にモデル化した研究は著者らの一連の研究以外では 皆無に等しい.

解析地点を積雪・融雪が少ない温暖な地域と, 積 雪・融雪が多い寒冷な地域の 2 地点を選び, 月平均 気温及び降水特性の時系列モデル構築し2，，2つ のシナリオを用いて将来を予測する. 1 つめは気温 の時系列モデルを用いた時系列シナリオ，2つめは 感度分析として、単純に現在の平均気温から $1{ }^{\circ} \mathrm{C}$ 上 昇させた $1{ }^{\circ} \mathrm{C}$ 上昇シナリオである. また予測した将 来の日降水特性から日流量の積率 (平均, 分散等) を推定するモデル ${ }^{3)}$ を用いて月蒸発散量及び月流 出量を推定する.

なお， $1{ }^{\circ} \mathrm{C}$ 上昇シナリオの設定根拠については, 日本各地, 各月とも月平均気温の標準偏差はおおよ そ $1{ }^{\circ} \mathrm{C}$ 前後 ${ }^{5)}$ であり,この程度の気温変化に対す 
る解析結果の信頼性は十分高いと考えているからで ある.

\section{2. 月平均気温及び降水特性の時系列モデル}

（1）月気温の平均值の時系列モデル

月平均気温の確率分布は正規分布に従うとし, 月 平均気温の平均值 $\overline{\theta_{i j}}$ が経年変化するとして, トレ ンド成分 $(T)$, 周期成分 $(S)$, 観測所の移動による ジャンプ $(I)$ の 3 成分による重ね合わせで表すと (1) 式のようになる.この説明変数のパラメー夕推 定には最尤法を用い, 最適化にはシンプレックス法 を用いる.ここでシンプレックス法を用いるにはパ ラメータに初期值を入力することが必要であるが, 本研究ではまず実デー夕を目的変数とした変数増減 法による重回帰分析を行い, その結果出力されたパ ラメータを初期値としている.

（2）降水特性の平均値の時系列モデル

図-1のように, 日単位で連続する雨（日降水量 0. $5 \mathrm{~mm}$ 以上）を一雨と定義する. 日降水量は双曲線 型指数分布 ${ }^{6)}$ に, 降水継続日数および無降水継続 日数は二变数指数型分布であるFreund分布 ${ }^{7)}$ に従 うことから，それぞれの平均值は確率分布のパラ メーターで表すことができる. そこで平均值を構成 している確率分布のパラメータの 1 つが経年変化し ていると考えて気温成分 $\left(\overline{\theta_{i j}}\right)$ ，トレンド成分

$(T)$ ，周期成分（ $S$ ） の重ね合わせの指数関数で 表す. 日降水量 $\left(u_{i j}\right)$ の平均值の時系列モデルを
(2) 式に, 降水継続日数 $\left(T r_{i j}\right)$ を(3) 式に無降水継 続日数 $\left(T b_{i j}\right)$ を(4) 式にそれぞれの平均值の時系 列モデルを示す

$$
\begin{gathered}
\overline{\theta_{i j}}=T_{\theta j}+S_{\theta j}+I_{\theta j} \\
\overline{u_{i j}}=k_{j} c_{j}+\exp \left(\overline{\theta_{i j}}+T_{w j}+S_{w j}\right) /\left(k_{j}-1\right) \\
\overline{T r_{i j}}=\frac{\left(\alpha_{2 j}+\beta_{1 j}\right)}{\alpha_{2 j}\left\{\exp \left(\overline{\theta_{i j}}+T_{T r j}+S_{T r j}\right)+\beta_{1 j}\right\}} \\
\overline{T b_{i j}}=\frac{\left(\alpha_{1 j}+\beta_{2 j}\right)}{\beta_{2 j}\left\{\exp \left(\overline{\theta_{i j}}+T_{T b j}+S_{T b j}\right)+\alpha_{1 j}\right\}} \\
\overline{N_{i j}}=D_{j} / \overline{T r_{i j}}+\overline{T b_{i j}}
\end{gathered}
$$

ここで, $\overline{u_{i j}}: i$ 年 $j$ 月の日降水量の平均値, $k_{j}$,

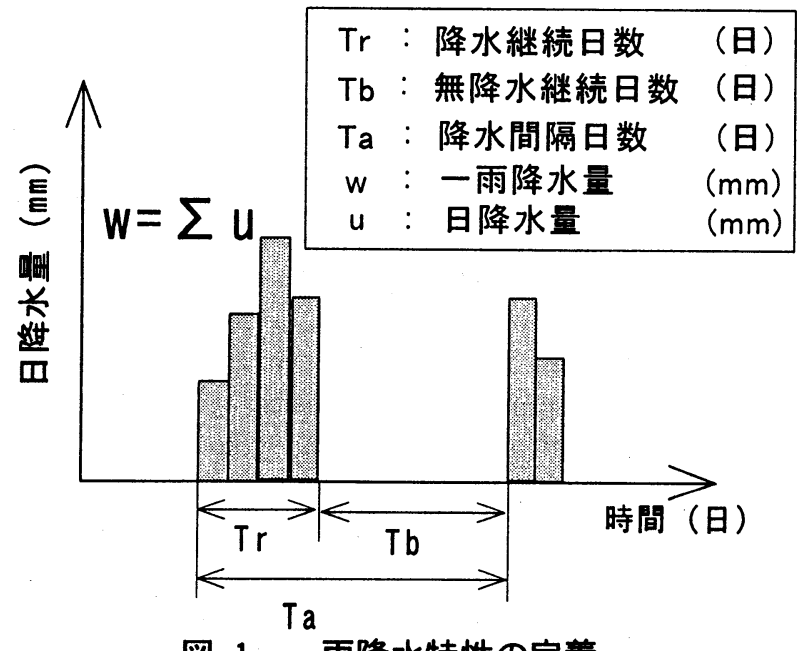

図-1 一雨降水特性の定義
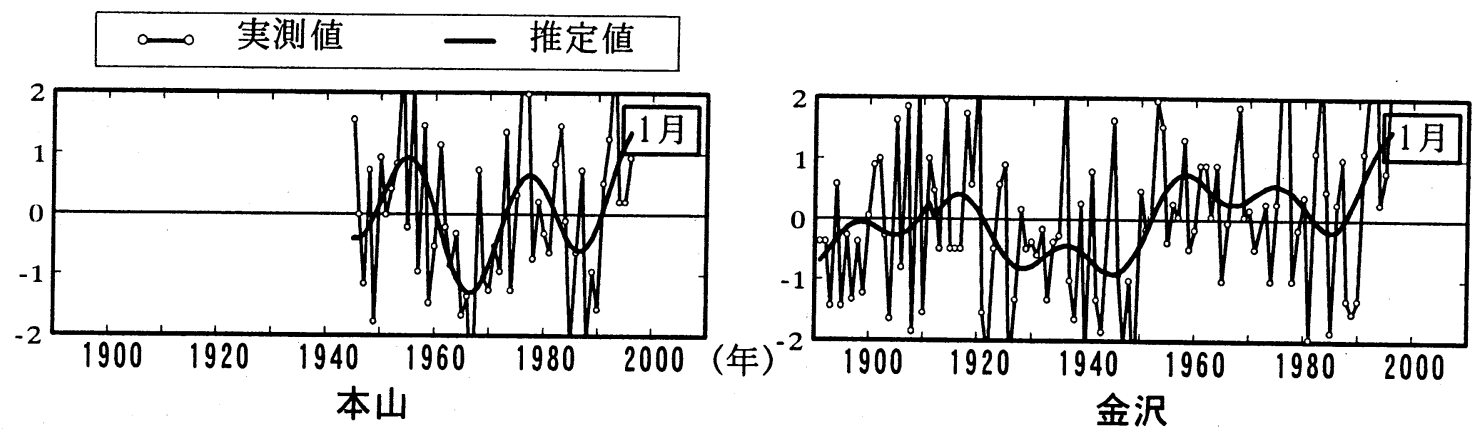

図-2 月平均気温の時系列変化
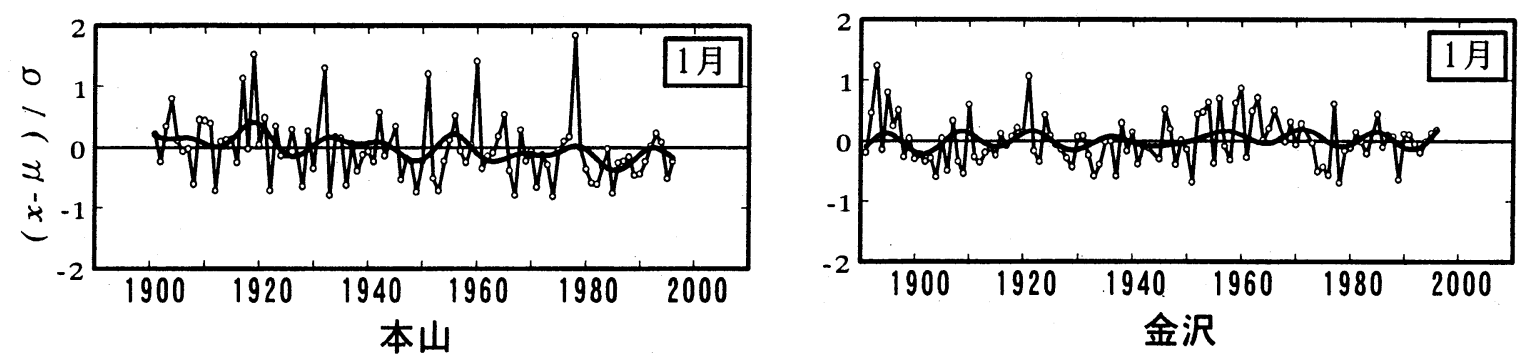

图-3 日降水量の平均値の時系列変化 

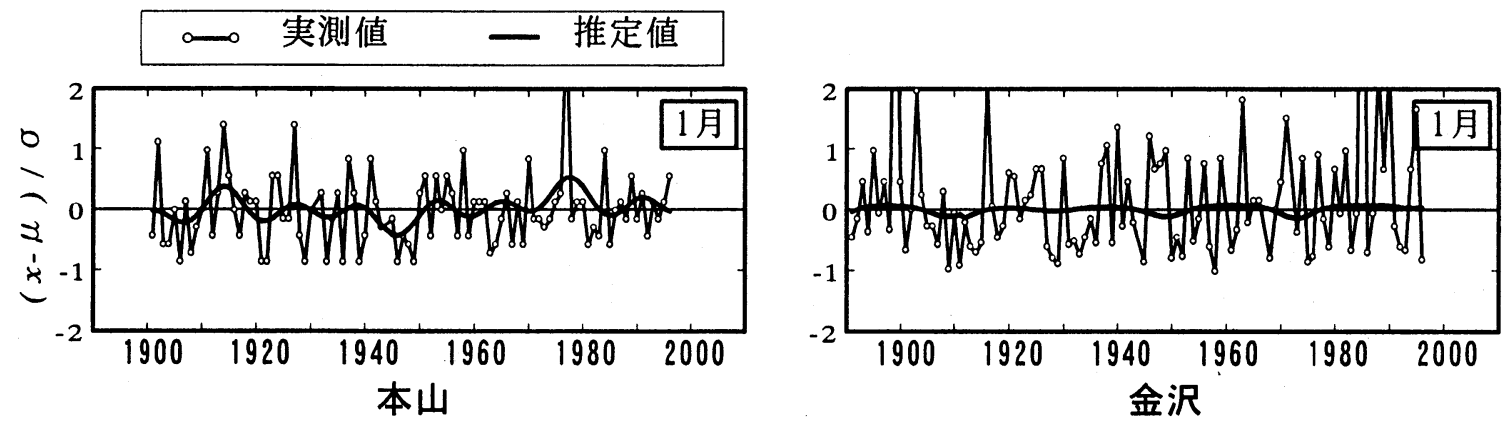

図-4 降水継続日数の平均值の時系列変化
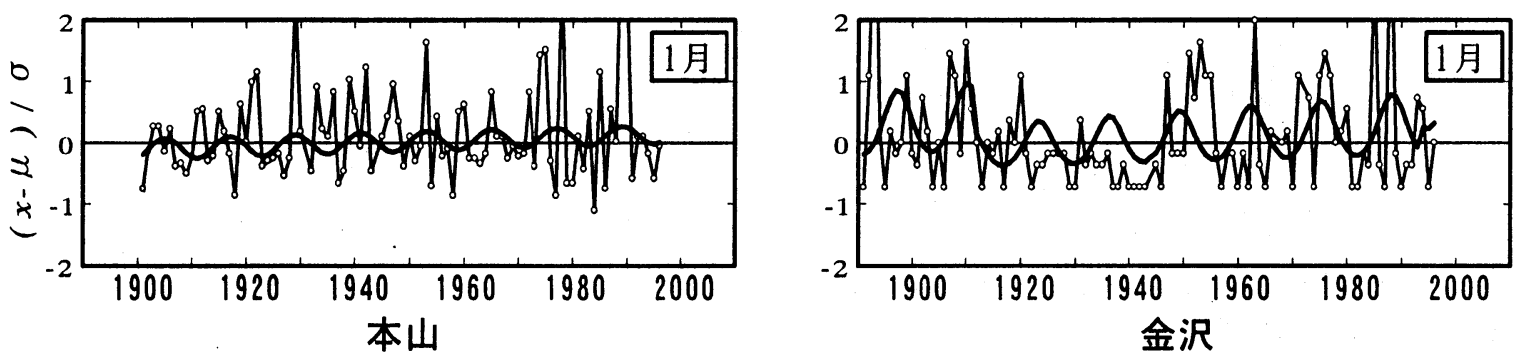

図-5 無降水継続日数の平均值の時系列変化

ここで, $\overline{u_{i j}}: i$ 年 $j$ 月の日降水量の平均値, $k_{j}$, $c_{j}$ : 双曲線型指数分布のパラメーター, $\overline{T r_{i j}}$ : 降水 継続日数の平均値, $\overline{T b_{i j}}$ : 無効水継続日数の平均値, $\alpha_{1 j}, \beta_{1 j}, \alpha_{2 j}, \beta_{2 j}$ : Freund 分布のパラメーター, $\overline{N_{i j}}$ : 一雨発生回数の月平均值， $D_{j}: 1$ ヶ月の日 数である. 降水特性の時系列モデルのパラメータに 関しても気温の時系列モデルと同じように最尤法を 用いて推定する.

月気温及び降水特性についてパラメータを同定し た結果を図-2〜5に示す. 図から時系列モデルは降 水特性の平均值の傾向をほぼ再現していると考えら れる. これらの降水特性の時系列モデルは, 平均值 の経年変化の有無を調べるという点では移動平均法 とよく似ているが, 決定的に違う点は将来の予測が 行えるということである.

\section{3. 積雪・融雪量, 日蒸散量, 日遮断蒸発量}

\section{を考虑したフィルタードポイント過程による 日流量の推定}

日降水特性から直接，ある月の日平均流量の平均， 分散, ひずみ係数および自己相関係数なる基本統計 量を計算する理論式がフィルタードポイント過程と して岳・端野らによって誘導されている ${ }^{31}$ 。降水 特性を日単位でなく一雨単位で整理することにより 十分な精度が得られているが，これらには積雪・融 雪量, 日蒸散量, 日遮断蒸発量が考慮されていない. そこで本研究では，このフィルタードポイント過程 に積雪・融雪量, 日遮断蒸発量, 日蒸散量を考慮に 入れた理論式を提案し，これを用いて流量の平均値
を求めることとする.フィルタードポイント過程と しての流出量は (6) 式のように日降水量に対する応 答の重ね合わせで与えられる ${ }^{3)}$.

$$
\begin{aligned}
& y_{t}=\sum_{n=1}^{N_{t}} u_{n} \cdot h\left(t-\tau_{n}\right)-T_{t}-F_{I t} \\
& T_{t}=a \cdot H_{t} \quad\left(r_{n}=0\right) \\
& F_{I t}=f_{p} \cdot r_{n} \cdot b \cdot H_{t} \quad\left(r_{n}>0\right) \\
& u_{n}= \begin{cases}f_{M} \cdot M_{n} & \left(\theta<\theta_{c}\right) \\
f_{p} \cdot r_{n} & \left(\theta \geq \theta_{c}\right)\end{cases} \\
& M_{n}= \begin{cases}g & \left(\theta<\theta_{c}\right) \\
g+\alpha\left(\theta-\theta_{c}\right)+\beta \frac{\left(\theta-\theta_{c}\right)}{80} f_{p} \cdot r_{n} & \left(\theta \geq \theta_{c}\right)\end{cases}
\end{aligned}
$$

ここで $h(s)$ は単位日流出量に対する流出量のパルス 線形応答関数, $N_{t}$ は一雨の発生回数, $T_{t}$ は日蒸散 量で, Hamon式のより求めた可能日蒸発散量 $H_{t}$ を用 いて (7) 式のように表し， $F_{I t}$ は遮断蒸発量で，日 可能蒸発散量と日降水量の積に比例すること ${ }^{8)}$ か ら (8) 式のように表す. $f_{p}$ は地点雨量 $r_{n}$ を流域平 均雨量にする補正係数であり， $f_{M}$ は $3 ， 4 ， 5$ 月 の消雪時期を考慮するために用いた融雪量の補正係 数である. $u_{n}$ についてはフィルタードポイント過 程では流域平均日降水量であるが，今回融雪を考慮 するため $u_{n}$ を(9) 式で与え, 融雪量 $M_{n}$ は (10) 式 のように表す.ここに $\mathrm{g}$ は, 地中の温度によって融 雪水が発生する, 地面融雪量 ${ }^{9)}$ であり， $\theta_{c}$ は降水 


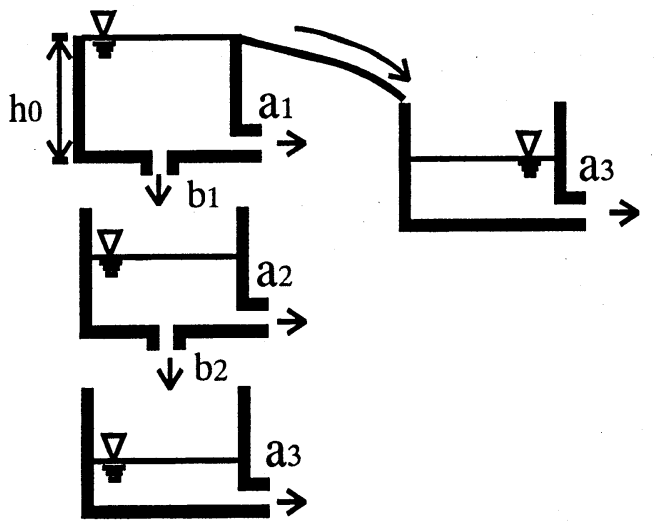

図-6 並列付加タンクモデル

また融雪が起こる気温（融雪気温）でもあるとする.

日流出量の線形応答関数には, 図-6に示すような 並列付加 3 段タンクモデルを設定した．これは直列 3 段タンクモデルに一段タンクを並列に置いたもの で, 表面流が卓越するような高水についても十分な 再現性が得られている ${ }^{3)}$ 。早明浦ダムと九頭竜ダ 厶流域の両解析地点において約 20 年間の流量と日 降水量データを用いてタンクモデルのパラメータ, 蒸散量, 遮断蒸発量の係数 $a, b$ 及び流域平均雨量 の補正係数 $f_{p}$ を同定する. 積雪・融雪係数 $(g$, $\alpha ， \beta)$ についてもシンプレックス法を用いて同 定を行う.

5 日平均流量 $Y_{t}$ の月平均 $\gamma_{1}\left(Y_{t}\right)$ を与える式は参考 文献3)の(19) 式より次式のように書くことができる.

$$
\begin{aligned}
D_{t} \cdot \gamma_{1}\left(Y_{t}\right)= & f_{p} \cdot\left\{E(r) \cdot \int_{0}^{D_{t}} h_{J}(s) d s\right. \\
& \cdot \sum_{n=1}^{D_{t} / 2} P\left[N_{c}=n\right] \cdot \sum_{j=1}^{n} \sum_{l_{j}=1}^{D_{t}-2 j+1} l_{j} \cdot P\left[T_{j}=l_{j}\right] \\
& +E\left(r_{s}\right) \cdot \int_{0}^{D_{t}} h_{J s}(s) d s \cdot \sum_{n=1}^{D_{f} / 2} P\left[N_{c s}=n\right] \\
& \left.\cdot \sum_{j=1}^{n} \sum_{l_{j}=1}^{D_{t}-2 j+1} l_{j} \cdot P\left[T_{s j}=l_{j}\right]\right\}+f_{M} \cdot E(M) \\
& \cdot \int_{0}^{D_{t}} h_{J}(s) d s-\sum_{n=1}^{D_{t}} T_{n}-\sum_{n=1}^{D_{t}} F_{I n}
\end{aligned}
$$

ここに， $D_{t}$ は対象月の日数， $E(r), E\left(r_{s}\right)$ は表面 流が発生しない一雨の平均日降水量, 表面流が発生 する一雨の平均日降水量であり, $h_{J}(s)$ は並列付加 3 段タンクモデルの直列部分の応答関数, $h_{J s}(s)$ は 並列付加（1 段タンク）の応答関数, $P[\cdot]$ は一雨に ついて $[\cdot]$ 内の取る確率, $N_{c}, N_{c s}$ はそれぞれある 年ある月の表面流の発生しない一雨の発生回数, 表
面流が発生する一雨の発生回数, $T_{j}, T_{j s}$ はそれぞ れある年ある月における表面流の発生しない一雨の 降水継続日数, 表面流が発生する一雨の降水継続日 数である.

\section{4. 気温シナリオによる将来の予測}

2. で述べた降水特性の時系列モデルは, 気温 成分を 1 つの説明変数としているため, 異なった気 温シナリオを想定し, 降水量の予測を行うことがで きる. そこで月平均気温の時系列モデルより求めた 将来(2026〜2055年)の各月の平均気温を用いる場合 （時系列シナリオ）と, 現在の平年気温（1966〜 1995年までの 30 年間の平均値）から一律に $1{ }^{\circ} \mathrm{C}$ 上昇 させた気温を将来の気温として用いる場合 $\left(1{ }^{\circ} \mathrm{C}\right.$ 上 昇シナリオ）の 2 つ気温シナリオについて解析を 行う. 時系列シナリオは過去の気温変動の傾向から 将来の気温を推定しているため実際の気温上昇に近 いと考えられる. また $1{ }^{\circ} \mathrm{C}$ 上昇シナリオついては, 前述したように月平均気温の標準偏差が $1^{\circ} \mathrm{C}$ 前後で あることより, 解析精度に信頼の置ける範囲での気 温上昇の影響の感度分析という位置づけで行う。

早明浦ダム流域で行った解析結果を図-7に示す。 各シナリオで求めた月気温, 月降水量, 月蒸発散量, 月流量の変化率を棒グラフで表し, 基準となる現在 の値（1966～1995年の30年間の平均值）を折れ線で 表した. まず気温の上昇率であるが，時系列シナリ オでは気温の上昇はさほど見られず，ほとんどの月 で0. $1 \sim 0.5^{\circ} \mathrm{C}$ の上昇で, 一番上昇している 2 月で約 $0.8^{\circ} \mathrm{C}$ の上昇である. 次に一雨発生回数と一雨降水 継続日数及び日降水量の積で与えられる月降水量の 変化を見ると, 夏場（7月〜10月）にかけて減少傾 向を示しているのが分かる. 時系列シナリオと $1{ }^{\circ} \mathrm{C}$ 上昇シナリオの7,8月の結果を見ると, 時系列シナ リオでは気温がほとんど上昇していないことより， 気温の影響というよりは, むしろ何らかの自然的要 因による影響の方が強いといえよう，しかし $1{ }^{\circ} \mathrm{C}$ 上 昇シナリオで気温が単純に $1^{\circ} \mathrm{C}$ 上昇した場合を見る と7 月では時系列シナリオの結果より大幅に減少し, 8月では逆に増加に転じている. これにより気温の 変化が夏場の降水量に影響を与えることが分かる.

冬場においては両シナリオ間にあまり差が見られず, 気温変化による降水への影響は少ないものと考えら れる. 月蒸発散量の変化については, 気温の增加に 従って増加傾向を示しており, 中でも夏場の増加が 目立つ. 月流量については降水量の変化に沿った増 減の仕方をしていることが分かる.

次に九頭竜ダム流域について解析した結果を図-8 に示す。時系列シナリオの気温上昇率が早明浦での 結果より冬場で大きくなっている. 月降水量につい ては，5月を除いて各月 $20 \%$ 程度の增減が見られる. わずかづつではあるが, $1{ }^{\circ} \mathrm{C}$ 上昇させた場合の方が 増減の程度が大きいことが読みとれる. 蒸発散量に ついては降水量が減少している月で増加傾向が見ら 

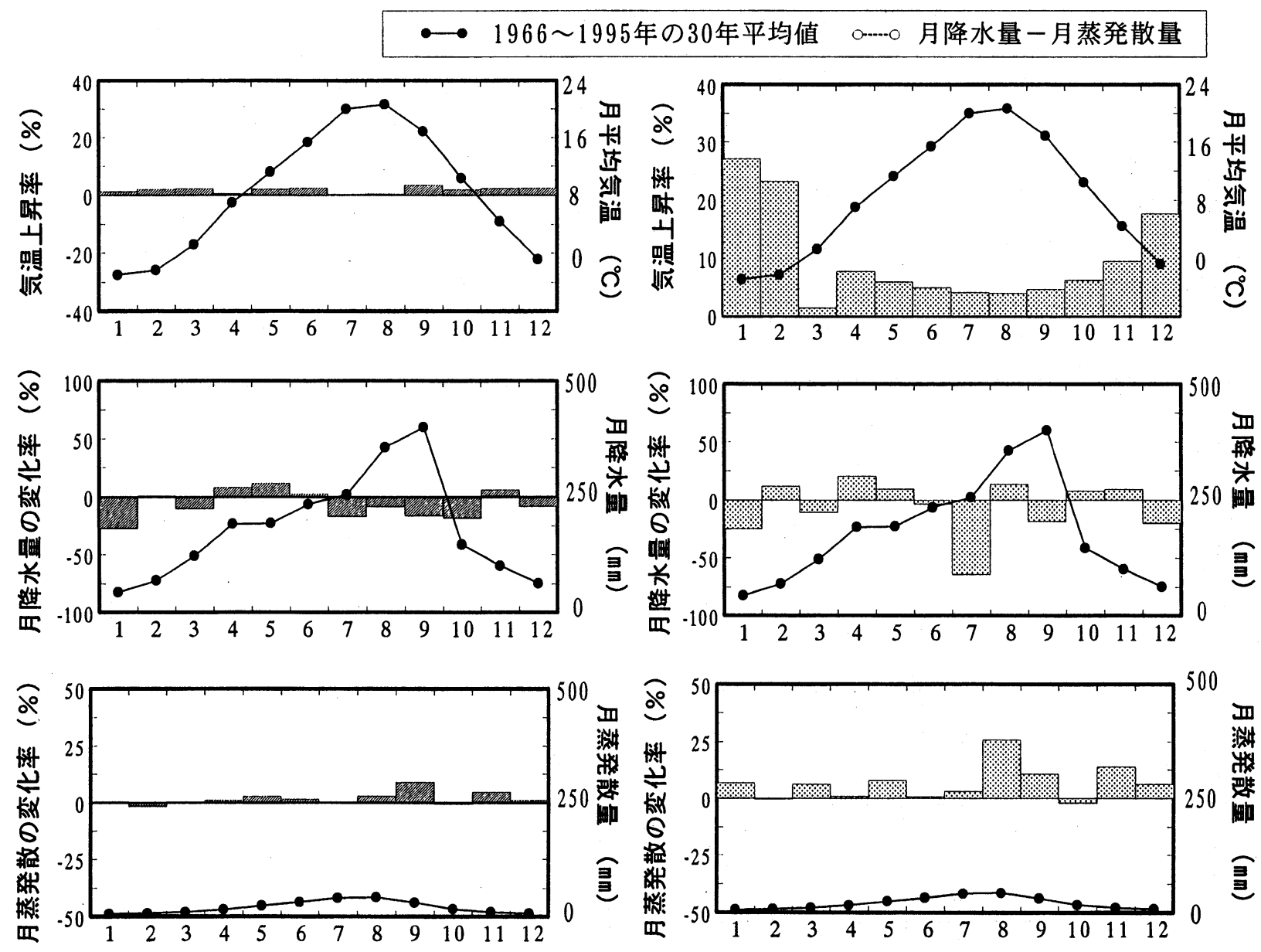

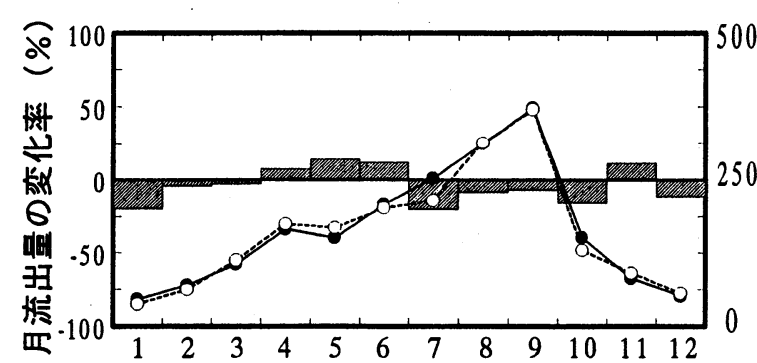

a) 時系列シナリオ

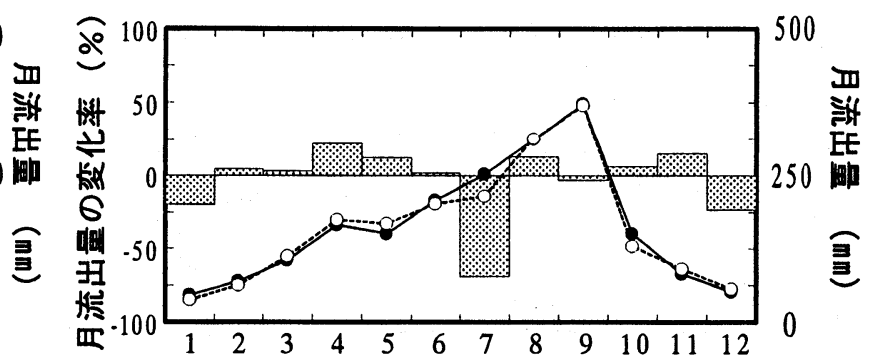

b) $1{ }^{\circ} \mathrm{C}$ 上昇シナリオ

图-7 早明浦ダム流域での将来予測

ついては降水量が減少している月で増加傾向が見ら れる. 次に流量の変化を見ると，2つのシナリオと も同様な增減の傾向を示していることが分かる. 積 雪期の $1 ， 2$ 月の流量が増え, 融雪期の $3 ， 4$ 月の 流量が減少している.これは気温の上昇により, 今 まで雪として降っていた降水が雨となって降るため 積雪としての流域貯留量が低下したためと考えられ る. また夏場において降水量の少ない 8 月を除くと 早明浦での解析と同様に, 月流量は降水量の増減に ほぼ従うことが分かる.

\section{5.あとがき}

本研究では, 水資源を考える立場から地球温暖 化にともない流出量がどのように影響を受けるのか を評価するため, 気温を考慮した降水特性の時系列 モデルを用いて, 月降水量, 月蒸発散量の平均值を 求める方法を提案した. また気温変化に伴う降水量 の変化は勿論のこと, 遮断蒸発, 蒸散, 積雪 ・融雪 を考慮に入れた, 月流量の平均值を求める方法を提 案した.

今回は流量の平均値だけの変化を取り上げたがこ の方法は流量の積率を考えているため, 流量の分散, ひずみ係数及び自己相関係数をも求めることができ る. したがってダムの管理計画に役立てることもで きると考えている. 

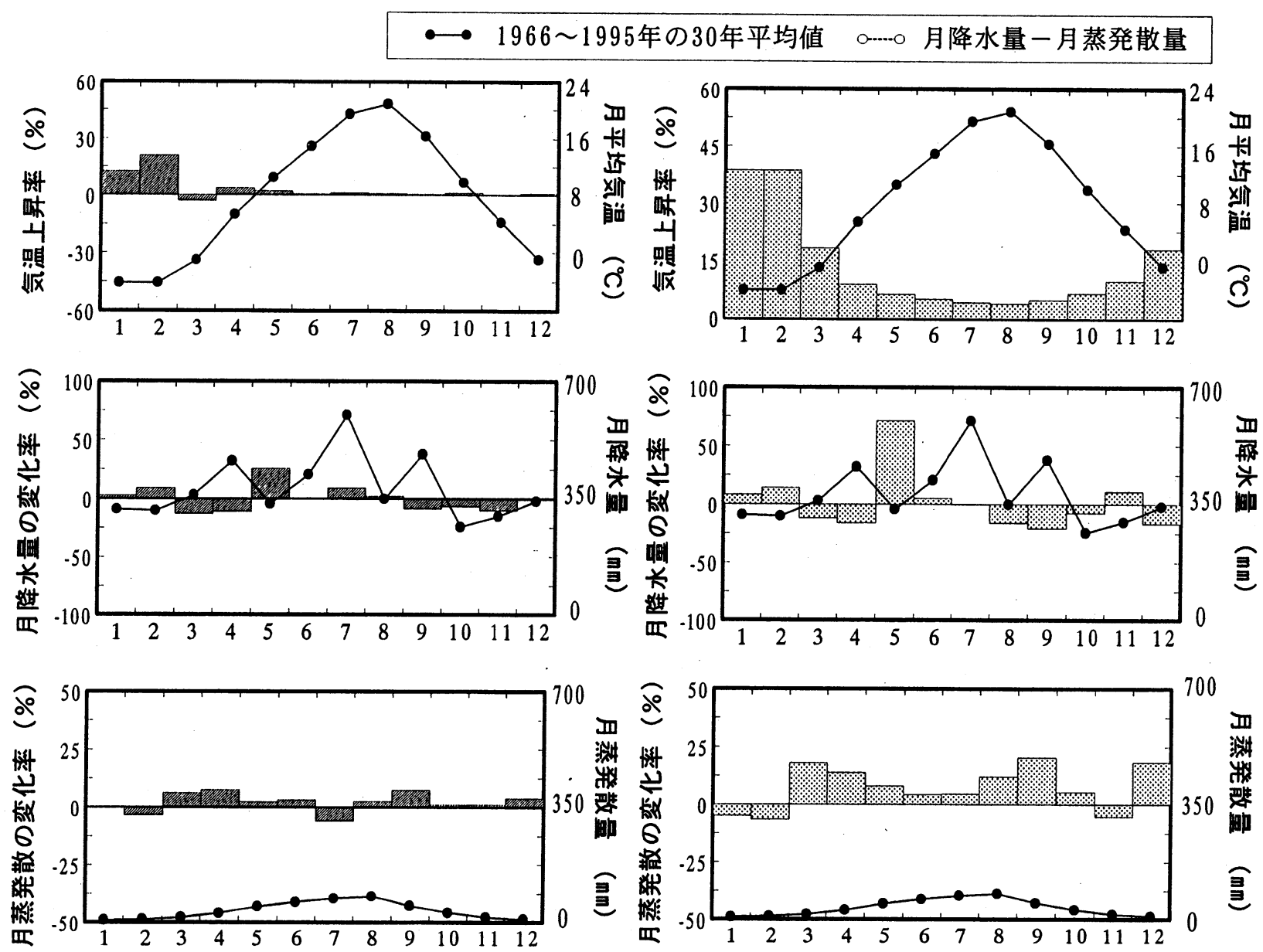

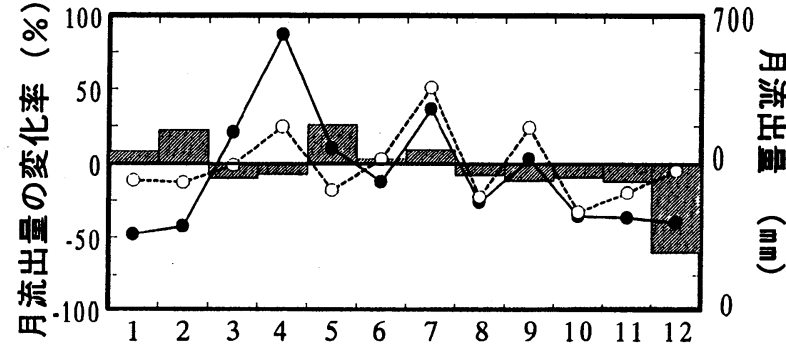

a). 時系列シナリオ

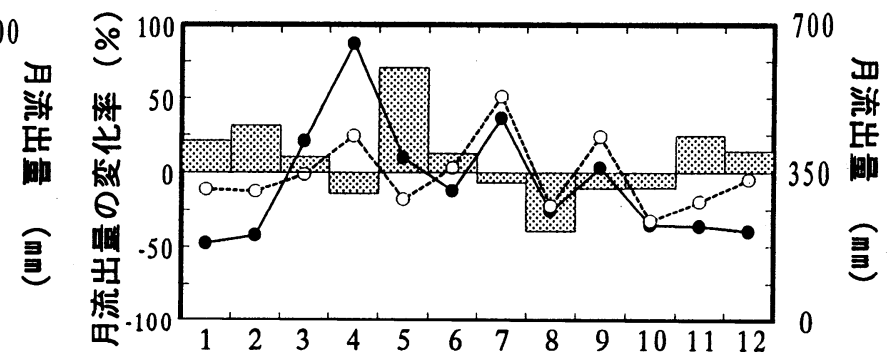

b) $1{ }^{\circ} \mathrm{C}$ 上昇シナリオ

図-8 九頭竜タム流域での将来予測

謝辞 : 本研究は科研費基盤研究 C（代表 端野道 夫）による研究成果の一部であることを記し，謝意 を表します。

\section{参考文献}

1) 気象庁編，温室効果気体の增加に伴う気温変化（II）, 大藏省印刷局, 1990 .

2) 名倉陽子・端野道夫 : 気温変動を考虑した降水量の時 系列解析, 第40回水工学論文集, pp347-352, 1996.

3) 岳生・端野道夫 : 日降水時系列デー夕を用いた日流出 量の積率推定法とその検証，土木学会論文集 N0533/ II-34, pp41-50, 1996.
4) 端野道夫・岳生 : 日本の主な気候区の月降水量特性に 及ぼす月平均気温特性の影響度の統計解析, 第 2 回地 球環境シンポジウム講演集, pp207-212, 1994.

5) 吉野正敏 : 気候学, 1968.

6) 角屋睦 : 水文統計論, 水工学シリーズ, 土木学会水理 委員会, 1964 .

7) 端野道夫・杉雄司 : 複数の 2 変数型分布の結合とその 応用に関する研究, 徳島大学工学部研究報告, 第29号, 1984.

8) 端野道夫 : 森林の水循環と水源かん養機能, 第33回水 工学に関する夏期研修会講義集，A-3，1997

9) 太田岳史 : 気温および降水量による山地積雪水量の経 時変化の推定, 水雪, 51 (1), pp33-43，1991。

（1997. 9. 30受付） 